\title{
PENGARUH KOMUNIKASI INTERPERSONAL \\ DAN KUALITAS PELAYANAN TERHADAP \\ KEPUASAN KONSUMEN
}

\author{
Enggarayu Weningtyas \\ Fakultas Psikologi dan Ilmu Sosial Budaya Universitas Islam Indonesia Yogyakarta \\ Email: ega_femmedoux@yahoo.co.id \\ Miftahun Ni'mah Suseno \\ Program Studi Psikologi Fakultas Ilmu Sosial dan Humaniora
Universitas Islam Negeri Sunan Kalijaga Yogyakarta
Email: miftahsuseno@gmail.com
}

\begin{abstract}
The General purpose of study was to determine the presence or absence of the influence of interpersonal communication and service quality toward consumer satisfaction. The hypothesis of this study is that there is the influence of interpersonal communication and service quality toward consumer satisfaction. The subject of this study were consumers who had visited Kalimilk. The subject of this study consisted of men and women aged 1823 years, totaling 60 people at try out and 60 people at the time of the study data collection. Data collected through the scale is was propagated to the subject of research. The data is was then statistically analyzed using multiple regression analysis with SPSS version 16.0 for Windows. The analysis found that the value $R=0.777$ with $p=0.000$ ( $p$ $<0.01)$. The magnitude of the coefficient of determination (R-Square) interpersonal communication and service quality to consumer satisfaction at $60.3 \%$ (0.603). The general conclusion of this study is was there is was a very significant positive effect between interpersonal communication and service quality toward consumer satisfaction. The higher the interpersonal communication skills and services quality provided employees the higher the consumer satisfaction.
\end{abstract}

Keywords: Interpersonal Communication, Service Quality, Consumer

Satisfaction

Dunia bisnis yang berorientasi pada produk maupun jasa tidak henti-hentinya berkompetisi untuk membuat konsumennya tetap setia pada produknya dan tidak berpaling ke produk lain. Salah satu kiat yang diyakini oleh pemasar untuk meraih hal tersebut adalah dengan menciptakan sistem pelayanan konsumen yang selalu mengarah kepada kepuasan konsumen (consumer satisfaction), seperti yang diungkapkan Kotler dan Armstrong (1999) bahwa kepuasan konsumen merupakan tingkat perasaan setelah membandingkan pelayanan yang dirasakan (perceived performance) dengan harapan (expectation). Salah satu faktor yang dapat memengaruhi kepuasan konsumen adalah komunikasi interpersonal. Hal tersebut dikemukakan Kotler dan
Armstrong (1999) bahwa konsumen akan lebih merasakan kepuasan dengan karyawan yang memiliki kemampuan dalam teknik berinteraksi dengan orang lain dan mempunyai kemampuan dalam persepsi sosial agar mampu membaca perasaan, sikap, dan keyakinan konsumen.

Pada saat terjadinya proses pelayanan yang dilakukan pelayan terhadap pelanggan, pada saat itu juga terjadi interaksi pelayan dengan pelanggan. Interaksi terjadi melalui kontak komunikasi. Pelayan harus bisa menciptakan kontak komunikasi pada pelanggan secara baik karena kontak komunikasi yang baik tersebut sangat dibutuhkan pelanggan untuk meningkatkan kinerja perusahaan dan untuk mempertahankan loyalitas konsumen. 
Komunikasi berlangsung dalam kontak tatap muka (face to face) di mana pesan-pesan mengalir melalui saluransaluran yang bersifat antar pesonal, seperti dalam percakapan antar orang perorang yang dikenal sebagai komunikasi interpersonal.

Berdasarkan hasil wawancara dengan beberapa manajer Kalimilk Yogyakarta, pihak Kalimilk berupaya melakukan pelayanan secara baik untuk memenuhi harapan dan kepuasan konsumen. Akan tetapi upaya tersebut dirasa belum sepenuhnya memuaskan konsumen. Masih banyak ditemukan pelayanan yang buruk dari karyawan Kalimilk terhadap konsumennya. Ada beberapa karyawan yang kurang ramah dalam melayani pelanggan ketika konsumen meminta bantuan, tidak ceria dalam melayani konsumen, bersikap kaku, tidak tersenyum, tidak mengucapkan salam, dan bahkan salah mengantar order pesanan untuk konsumen.

Beberapa hal tersebut merupakan salah satu faktor yang menimbulkan ketidakpuasan konsumen. Pihak Kalimilk merasa bahwa kualitas pelayanan dari karyawan yang bekerja di tempat tersebut belum sepenuhnya optimal. Hal itu terlihat dari banyaknya keluhan yang masuk dari konsumen.

Wawancara juga dilakukan penulis kepada konsumen Kalimilk. Hasil wawancara menunjukkan bahwa masih ada harapan konsumen yang belum tercapai. Bentuk ketidakpuasan terhadap pelayanan yang dilakukan oleh karyawan dapat dilihat dari keluhan mereka, misalnya subjek A menyatakan bahwa kualitas pelayanan di Kalimilk masih kurang. Ketika memesan pesanan, subjek A kurang mendapatkan pelayanan yang ramah dan tidak merespon apa yang diharapkan secara cepat. Kedua, ketika ramai pengunjung subjek A harus mengantri untuk menunggu cukup lama. Hal twesebut membuat subjek A bosan dan merasa kurang nyaman.

Hal berbeda ditunjukkan dari hasil wawancara dengan subjek B. Subjek B menyatakan bahwa ketika mengajak berbicara, karyawan kurang merespon secara baik terhadap apa yang diinginkan subjek. Subjek C mengalami pengalaman yang berbeda ketika berada di Kalimilk. Subjek C menyatakan bahwa pelayanannya kurang sistematis. Karyawan tidak mengulang daftar order yang dipesan oleh subjek C sehingga terjadi kesalahan order.

Sesuai dengan penerapan sistem pelayanan yang serba cepat dalam era globalisasi ini, penerapan manajemen kualitas dalam industri jasa telah menjadi kebutuhan pokok apabila industri jasa ingin berkompetensi dalam pasar global maupun pasar domestik Indonesia. Tuntutan konsumen Indonesia terhadap tingkat pelayanan yang diberikan oleh produsen industri jasa terus meningkat, sehingga manajemen industri jasa ditantang untuk mengembangkan sistem manajemen kualitas agar dapat meningkatkan kepuasan konsumennya.

Kepuasan konsumen merupakan perbedaan/kesenjangan antara harapan sebelum pembelian dengan kinerja atau hasil yang dirasakan setelah pembelian. Kepuasan konsumen dapat dilihat dari faktor performance dan expectation.

Menurut Levy dan Weitz (2001), ada empat aspek kepuasan konsumen, yang meliputi:

1. Pengetahuan konsumen akan produk dan jasa (Costumer Knowledge).

2. Pengalaman yang diperoleh konsumen (Costumer Experiences).

3. Pelayanan terhadap konsumen yang diberikan penyedia jasa (Perceived Service).

4. Konsumen termotivasi untuk mengevaluasi kulaitas pelayana (Situation Producing Satisfactory).

Kepuasan konsumen dipengaruhi oleh beberapa faktor pendorong, seperti komunikasi interpersonal dan kualitas pelayanan. Komunikasi interpersonal adalah suatu proses sosial di mana di dalamnya mengandung unsur keterbukaan, empati, dukungan, kepositifan, kesamaan, keyakinan, kesiapan, yang kemudian timbul kepercayaan, sikap mendukung, dan mendorong timbulnya sikap saling memahami dan menghargai.

De Vito (1997) menyatakan agar 
komunikasi interpersonal berlangsung dengan efektif, maka ada beberapa aspek yang harus diperhatikan, yaitu:

1. Keterbukaan, yaitu kesediaan untuk membuka diri dalam mengungkapkan informasi secara jujur sesuai dengan keadaan yang sebenarnya dalam berinteraksi.

2. Empati, yaitu kemampuan seseorang mengetahui apa yang sedang dialami orang lain pada saat tertentu, dari sudut pandang orang lain, melalui kaca mata orang lain.

3. Sikap mendukung. Dukungan meliputi tiga hal. Pertama, descriptiveness, yaitu suasana yang bersifat deskriptif dan bukan evaluatif membantu terciptanya sikap mendukung. Kedua, spontanity yaitu kemampuan seseorang untuk berkomunikasi secara spontan dan terus terang yang mempunyai sikap terbuka dalam menyampaikan pemikirannya. Ketiga, provisionalism, dipahami sebagai kemampuan untuk berpikir secara terbuka (open minded).

4. Sikap positif, yaitu kemampuan seseorang dalam memandang dirinya secara positif dan berperasaan positif pada saat berkomunikasi.

5. Kesetaraan. Komunikasi interpersonal akan efektif apabila suasananya setara. Artinya, harus ada pengakuan dari kedua belah pihak sama-sama bernilai dan berharga dan ada sesuatu yang penting untuk disumbangkan.

Selain komunikasi interpersonal, kepuasan konsumen juga dipengaruhi kualitas pelayanan. Kualitas pelayanan adalah performasi karyawan dalam menyajikan produkatau jasa sesuai dengan standar dan ukuran yang berlaku pada produk atau jasa tersebut yang dipengaruhi oleh perilaku karyawan untuk memenuhi harapan dan kebutuhan pelanggan.

Lima dimensi kualitas pelayanan kepada pelanggan menurut Zeithaml dan Bitner(2000), yaitu:

1. Kehandalan (Reliability) adalah kemampuan memberikan pelayanan yang dijanjikan dengan segera, akurat, dan memuaskan.

2. Daya Tanggap (Responsiveness) merupakan keinginan untuk membantu pelanggan dan memberikan pelayanan dengan tanggap terhadap kebutuhan pelanggan, cepat memberi respon terhadap permintaan pelanggan, dan cepat memperhatikan serta mengatasi $\mathrm{k} \mathrm{e} \mathrm{b} \mathrm{u} \mathrm{t} \mathrm{u} \mathrm{h} \mathrm{a} \mathrm{n} \mathrm{p} \mathrm{e} \mathrm{la} \mathrm{n} \mathrm{g} \mathrm{g} \mathrm{a}$.

3. Jaminan (Assurance), yaitu pengetahuan, kesopanan, dan kemampuan untuk membangkitkan kepercayaan pelanggan dan membuat pelanggan merasa aman.

4. Empati (Emphaty) merupakan kemampaun karyawan dalam memberikan perhatian individual dan memahami kebutuhan pelanggan.

5. Bukti Langsung (Tangibles) merupakan penampakan dan penampilan fisik, peralatan, karyawan, dan material tertulis.

Berdasarkan uraian di atas dapat diasumsikan bahwa komunikasi interpersonal dan kualitas pelayanan memiliki pengaruh terhadap kepuasaan konsumen. Dengan demikian akan diteliti pengaruh komunikasi interpersonal dan kualiras pelayanan terhadap kepuasaan konsumen.

Adapun hipotesis penelitian yang diajukan adalah ada pengaruh positif komunikasi interpersonal dan kualitas pelayanan terhadap kepuasan konsumen.

\section{METODE PENELITIAN}

\section{Subjek Penelitian}

Subjek dalam penelitian ini adalah konsumen yang pernah mengunjungi Kalimilk berjenis kelamin laki-laki dan perempuan dengan usia 18-23 tahun sebanyak 60 orang.

\section{Alat Ukur}

Metode yang digunakan dalam penelitian ini adalah dengan menggunakan skala. Peneliti menggunakan tiga buah skala untuk mengukur ketiga variabel, yaitu skala kepuasan konsumen, skala komunikasi interpersonal dan skala kualitas pelayanan. 
Skala kepuasan konsumen dalam penelitian ini menggunakan skala yang dibuat oleh peneliti sendiri berdasarkan aspek-aspek dan dikemukakan Levy dan Weitz (2001) yang terdiri atas pengetahuan konsumen akan produk dan jasa (costumer knowledge), pengalaman yang diperoleh konsumen (costumer experiences), pelayanan terhadap konsumen yang diberikan penyedia jasa (perceived service), dan konsumen termotivasi untuk mengevaluasi kualitas pelayanan (situation producing satisfactory). Skala ini terdiri dari 16 aitem, 4 aitem favorable dan 12 aitem unfavorable.

Begitupun skala komunikasi interpersonal yang digunakan dalam penelitian ini menggunakan skala yang dibuat oleh peneliti sendiri berdasarkan aspek-aspek dari De Vito (1997), yaitu keterbukaan, empati, dukungan, kepositifan, dan kesamaan. Skala ini terdiri dari 20 aitem, terbagi atas 5 aitem favorable dan 15 aitem unfavorable.

Skala kualitas pelayanan yang digunakan dalam penelitian ini dibuat sendiri oleh peneliti sendiri berdasarkan aspekaspek yang dikemukakan Zeithaml dan Bitner (2000), yaitu dengan cara membuat pernyataan yang meliputi aspek-aspek: Bukti Langsung (Tangibles), Keandalan (Reliability), Jaminan (Assurance), Daya Tanggap (Responsiveness), dan Empati (Empathy). Skala ini terdiri dari 20 aitem, yang terbagi atas 6 aitem favorable dan 14 aitem unfavorable. Empat alternatif jawaban yang disediakan, yaitu Sangat Setuju (SS) bernilai 4, Setuju (S) bernilai 3, Tidak Setuju (TS) bernilai 2, Sangat Tidak Setuju (STS) bernilai 1. Sedangkan pada aitem unfavorable skor yang diberikan yaitu Sangat Setuju (SS) bernilai 1, Setuju (S) bernilai 2, Tidak Setuju (TS) bernilai 3, Sangat Tidak Setuju (STS) bernilai 4. Dari keseluruhan jawaban subjek, kemudian diperoleh skor-skor dari tiap aitem. Keseluruhan skor tersebut dijumlahkan. Skor total yang diakumulasikan menunjukkan tinggi rendahnya kepuasan konsumen, komunikasi interpersonal dan kualitas pelayanan.

Metode analisis statistik yang digunakan untuk menguji hipotesis adalah analisis regresi ganda. Analisis regresi ganda digunakan karena merupakan analisis peramalan yang dapat dipakai untuk menguji nilai pengaruh dua variabel bebas atau lebih terhadap variabel terikat. Perhitungan statistik ini dilakukan dengan komputasi melalui bantuan program Statistical Product and Service Solutions (SPSS) 16.0 for Windows.

\section{HASIL PENELITIAN}

\section{Deskripsi Subjek Penelitian}

Deskripsi subjek penelitian secara jelas diperlihatkan pada tabel 1 berikut ini :

Tabel 1. Deskripsi Subjek Penelitian

\begin{tabular}{lllc}
\hline No & Faktor & \multicolumn{1}{c}{ Kategori } & Jumlah \\
\hline 1. & Jenis Kelamin & Laki-laki & 12 \\
& & Perempuan & 48 \\
\multirow{2}{*}{2} & \multirow{2}{*}{ Usia } & $>20$ tahun & 19 \\
& & $15-20$ & 41 \\
\hline
\end{tabular}

Pembuatan kategorisasi subjek terbagi dalam 5 kategori yaitu sangat tinggi, tinggi, sedang, rendah dan sangat rendah. Kategori sangat tinggi, tinggi, sedang, rendah dan sangat rendah ini dibuat berdasarkan perhitungan kategorisasi menggunakan mean hipotetik dandeviasi standar. Data deskripsi skor hipotetik untuk perhitungan kategorisasi dan data skor empirik dapat dilihat pada tabel 2 di bawah ini:

Tabel 2.

Deskripsi Statistik Data Penelitian

\begin{tabular}{|l|c|c|c|c|c|c|c|c|}
\hline \multirow{2}{*}{ Variabel } & \multicolumn{4}{|c|}{ Hipotetik } & \multicolumn{4}{|c|}{ Empirik } \\
\cline { 2 - 9 } & Min & Max & Mean & SD & Min & Max & Mean & SD \\
\hline $\begin{array}{l}\text { Kepuasan } \\
\text { Konsumen }\end{array}$ & 16 & 64 & 40 & 8 & 30 & 57 & 43,78 & 4,727 \\
\hline $\begin{array}{l}\text { Komunikasi } \\
\text { Interpersonal }\end{array}$ & 20 & 80 & 50 & 10 & 44 & 68 & 57,03 & 4,812 \\
\hline $\begin{array}{l}\text { Kualitas } \\
\text { Pelayanan }\end{array}$ & 20 & 80 & 50 & 10 & 37 & 63 & 54,18 & 5,610 \\
\hline
\end{tabular}

Berikut kategorisasi subjek penelitian untuk masing-masing variabel penelitian:

Tabel 3 .Kategorisasi Variabel Kepuasan Konsumen

\begin{tabular}{llcc}
\hline \multicolumn{1}{c}{ Kategori } & Rentang skor & Jumlah & Prosentase \\
\hline Sangat Tinggi & $X>54,4$ & 1 & $2 \%$ \\
Tinggi & $44,8 \leq X<$ & 54,427 & $45 \%$ \\
Sedang & $35,2 \leq X 44,8$ & 27 & $45 \%$ \\
Rendah & $25,6 \leq X<$ & 35,25 & $8 \%$ \\
Sangat Rendah & $X<25,6$ & 0 & $0 \%$ \\
\hline
\end{tabular}


Kategorisasi variabel kepuasan konsumen untuk kategori sangat rendah tidak ada, kategori rendah ada 5 subjek (8\%), kategori sedang ada 27 subjek (45\%), kategori tinggi ada 27 subjek (45\%), sedangkan kategori sangat tinggi ada 1 subjek (2\%). Berdasarkan kategori tabel di atas, variabel kepuasan konsumen sebagian besar dalam kategori tinggi dan sedang.

Tabel 4. Kategorisasi Variabel Komunikasi Interpersonal

\begin{tabular}{lcccc}
\multicolumn{1}{r}{ Kategori } & Rentang skor & & Jumlah & Prosentase \\
\hline Sangat Tinggi & $\mathrm{X}>68$ & & 0 & $0 \%$ \\
Tinggi & $56 \leq \mathrm{X}<68$ & 37 & $62 \%$ \\
Sedang & $44 \leq \mathrm{X}<56$ & 21 & $35 \%$ \\
Rendah & $32 \leq \mathrm{X}<44$ & 2 & $3 \%$ \\
Sangat Rendah & $\mathrm{X}<32$ & & 0 & $0 \%$ \\
\hline
\end{tabular}

Kategorisasi variabel komunikasi interpersonal untuk kategori sangat rendah tidak ada, kategori rendah ada 2 subjek (3\%), kategori sedang ada 21 subjek (35\%), kategori tinggi ada 37 subjek (62\%), sedangkan kategori sangat tinggi tidak ada. Berdasarkan kategori tabel di atas, variabel komunikasi interpersonal sebagian besar dalam kategori tinggi.

Tabel 5 .Kategorisasi Variabel Kualitas

\begin{tabular}{lcccc}
\multicolumn{4}{c}{ Pelayanan } \\
\hline \multicolumn{1}{c}{ Kategori } & Rentang skor & Jumlah & Prosentase \\
\hline Sangat Tinggi & $\mathrm{X}>68$ & & 0 & $0 \%$ \\
Tinggi & $56 \leq \mathrm{X}<68$ & 29 & $48 \%$ \\
Sedang & $44 \leq \mathrm{X}<56$ & 28 & $47 \%$ \\
Rendah & $32 \leq \mathrm{X}<44$ & 3 & $5 \%$ \\
Sangat Rendah & $\mathrm{X}<32$ & & 0 & $0 \%$ \\
\hline
\end{tabular}

Kategorisasi variabel kualitas pelayanan untuk kategori sangat rendah tidak ada, kategori rendah ada 3 subjek (5\%), kategori sedang ada 28 subjek (47\%), kategori tinggi ada 29 subjek (48\%), sedangkan kategori sangat tinggi tidak ada. Berdasarkan kategori tabel di atas, variabel kualitas pelayanan sebagian besar dalam kategori tinggi.

\section{Hasil Uji Asumsi}

Sebelum dilakukan uji hipotesis dengan menggunakan analisis regresi, maka terlebih dahulu dilakukan uji asumsi normalitas dan linieritas. Hal ini dilakukan untuk mengetahui apakah data subjek penelitian mengikuti kurve normal yang menunjukkan representatif subjek penelitian terhadap populasi dan uji linieritas untuk mengetahui apakah masing-masing variabel bebas mengikuti garis linier terhadap variabel tergantung. Berikut hasil uji asumsi normalitas dan linieritas:

\section{Tabel 6. Hasil Uji Normalitas}

\begin{tabular}{lccc}
\hline \multicolumn{1}{c}{ Variabel } & KS-Z & $\mathrm{p}$ & Keterangan \\
\hline Kepuasan Konsumen & 1,185 & 0,121 & Normal \\
Komunikasi Interpersonal & 1,149 & 0,143 & Normal \\
Kualitas Pelayanan & 1,360 & 0,050 & Normal \\
\hline
\end{tabular}

Hasil uji normalitas sebaran data menunjukkan bahwa sebaran untuk variabel kepuasan konsumen dengan $\mathrm{KS}-\mathrm{Z}=1,185 ; \mathrm{p}$ $=0,121(\mathrm{p}>0,05)$, sehingga sebaran untuk variabel ini normal. Untuk hasil uji normalitas sebaran untuk variabel komunikasi interpersonal dengan $\mathrm{KS}-\mathrm{Z}=$ 1,$149 ; p=0,143(p>0,05)$, sehingga sebaran untuk variabel ini normal. Sedangkan, hasil uji normalitas sebaran data menunjukkan bahwa sebaran untuk variabel kualitas pelayanan dengan $\mathrm{KS}-\mathrm{Z}=1,360 ; \mathrm{p}=0,050$ $(\mathrm{p}>0,05)$, sehingga sebaran untuk variabel ini normal.

Tabel 7.Hasil Uji Linieritas

\begin{tabular}{lccc}
\hline \multicolumn{1}{c}{ Variabel } & $\mathrm{F}$ & $\mathrm{p}$ & Keterangan \\
\hline $\begin{array}{l}\text { Kepuasan Konsumen* } \\
\text { Komunikasi Interpersonal }\end{array}$ & 58,259 & 0,000 & Linier \\
$\begin{array}{l}\text { Kepuasan Konsumen* } \\
\text { Kualitas Pelayanan }\end{array}$ & $* 84,083$ & 0,000 & Linier \\
\hline
\end{tabular}

Hasil uji linearitas dalam penelitian ini menunjukkan hubungan antara kepuasan konsumen dan komunikasi interpersonal menghasilkan nilai $\mathrm{F}=58,253$ dengan $\mathrm{p}=$ $0,000 \quad(p<0,05)$. Dengan demikian, dapat disimpulkan bahwa hubungan antara komunikasi interpersonal dan kepuasan konsumen bersifat linier. Sedangkan, hasil uji linearitas yang menunjukkan hubungan antara kepuasan konsumen dan kualitas pelayanan menghasilkan nilai $\mathrm{F}=84,083$ dengan $p=0,000 \quad(p<0,05)$. Dengan demikian, dapat disimpulkan bahwa hubungan antara kualitas pelayanan dan kepuasan konsumen bersifat linier.

\section{Hasil Uji Hipotesis}

Berdasarkan hasil analisis regresi diperoleh hasil penelitian sebagai berikut:

1. Hipotesis Mayor

Dari hasil analisis regresi diperoleh skor $r_{x y}(R)=0,777 ; p=0,000(p<0,01)$. Hal ini menunjukkan ada pengaruh komunikasi 
interpersonal dan kualitas pelayanan yang sangat signifikan terhadap kepuasan konsumen. Hasil lain yang diperoleh adalah nilai koefisien determinasi (R-Square) sebesar 0,603 yang berarti bahwa kepuasan konsumen dipengaruhi sebesar $60,3 \%$ oleh variabel komunikasi interpersonal dan kualitas pelayanan, sedangkan sisanya $39,7 \%$ dipengaruhi faktor-faktor yang lain.

2. Hipotesis Minor

a. Hasil analisis yang diperoleh dari variabel komunikasi interpersonal memiliki nilai $r=0,239 ; \mathrm{p}=0,006$ $(p<0,05)$, maka hipotesis diterima. Hal ini terbukti bahwa komunikasi berpengaruh signifikan terhadap kepuasan konsumen. Nilai koefisien determinasi yang ditunjukkan oleh $R$ Square adalah 0,057. Angka tersebut menunjukkan bahwa komunikasi interpersonal memberikan sumbangan efektif sebesar 5,7\%.

b. Hasil analisis yang diperoleh dari variabel kualitas pelayanan memiliki nilai $r=0,739 ; p=0,000(p<0,01)$, maka hipotesis diterima. Hal ini terbukti bahwa kualitas pelayanan berpengaruh signifikan terhadap kepuasan konsumen. Nilai koefisien determinasi yang ditunjukkan oleh $R$ Square adalah 0,546. Angka tersebut menunjukkan bahwa kualitas pelayanan memberikan sumbangan efektif sebesar $54,6 \%$.

\section{PEMBAHASAN}

Berdasarkan hasil analisis data penelitian, maka hipotesis yang telah diajukan, yaitu ada pengaruh positif antara komunikasi interpersonal dan kualitas pelayanan terhadap kepuasan konsumen dapat diterima. Semakin tinggi komunikasi interpersonal dan kualitas pelayanan maka semakin tinggi pula kepuasan konsumen. Sebaliknya, semakin rendah komunikasi interpersonal dan kualitas pelayanan, maka semakin rendah pula kepuasan konsumen yang dirasakan.

Kepuasan dan ketidakpuasan konsumen dapat dipengaruhi oleh faktor pengalaman mengkonsumsi produk atau jasa sebelumnya (Surya \& Setiyaningrum, 2009). Keadaan kualitas jasa yang dirasakan oleh konsumen Kalimilk adalah perasaan dan sikap dari seorang konsumen terhadap pelayanan yang dirasakan dan disesuaikan dengan pelayanan yang diharapkannya. Fitzimmons dan Fitzimmons (Putra, 2009) mengatakan kepuasan konsumen dengan layanan dapat diartikan dengan membandingkan persepsi pelayanan servis dengan harapan yang diinginkan konsumen. Expected service menunjukkan ekspektasi konsumen terhadap pelayanan yang merupakan fungsi dari kebutuhan personal, komunikasi dari mulut ke mulut, dan pengalaman yang lalu. Sedangkan perceived service a d a la h ja s a $\mathrm{y} \mathrm{ng}$ dirasakanberdasarkan persepsi konsumen.

Saat Proses pelayanan yang dilakukan oleh karyawan terhadap konsumen terjadi interaksi pelayan dengan konsumen. Interaksi terjadi melalui kontak komunikasi. Karyawan harus bisa menciptakan kontak komunikasi yang baik dengan konsumen karena kontak komunikasi yang baik tersebut menjadi salah satu faktor yang menentukkan puas atau tidaknya konsumen terhadap pelayanan yang diberikan. Hal ini searah dengan penelitian yang dilakukan oleh Putra (2009) bahwa pendekatan yang profesional, ketrampilan interpersonal yang baik, kemampuan berkomunikasi, sikap yang positif, pengetahuan produk yang baik, dan faktor senyuman, dapat berperan pada suatu citra dan tingkat kepuasan konsumen yang selanjutnya menjadi pendorong kerelasian konsumen dengan perusahaan. Hasil penelitian ini juga membuktikan bahwa kualitas pelayanan merupakan faktor yang paling mempengaruhi kepuasan konsumen. Hal ini dapat dilihat dari nilai sumbangan efektif dari kualitas pelayanan terhadap kepuasan konsumen yaitu sebesar $54,6 \%$. Peran kualitas pelayanan terhadap kepuasan konsumen memiliki pengaruh yang lebih besar dibanding dengan komunikasi interpersonal karyawan dengan konsumen. Dengan demikian, dapat dikatakan bahwa konsumen yang mempunyai kepuasan yang tinggi adalah 
konsumen yang memandang atau merasakan pelayanan yang diberikan karyawan sudah sesuai dengan harapannya.

Adanya pengaruh yang positif kualitas pelayanan terhadap kepuasan konsumen senada dengan pendapat Gerson (2004) yang menyatakan bahwa memberikan mutu yang tinggi dan pelayanan yang prima adalah suatu keharusan di dalam mencapai tujuan utama konsumen, yaitu kepuasan dan kesetiaan. Hal ini sebagaimana penelitianpenelitian Hendrajana (Wijoyo \& Wahyudin, 2005), yang mengungkapkan bahwa kualitas pelayanan berpengaruh pada tingkat kepuasan, Hal senada diungkapkan oleh Wahyudin dan Muryati (Wijoyo \& Wahyudi, 2005) dalam penelitiannya bahwa terdapat pengaruh yang sangat signifikan antara variabel atribut produk, pelayanan, dan harga terhadap kepuasan konsumen. Penelitian lain yang dilakukan oleh Gunawan (Wijoyo \& Wahyudin, 2005), menunjukkan bahwa terdapat pengaruh yang signifikan antara lima dimensi service quality for retail store terhadap kepuasan pelanggan.

Dengan demikian, dapat disimpulkan bahwa kualitas pelayanan memiliki pengaruh yang signifikan terhadap kepuasan konsumen. Kepuasan konsumen melakukan peran mediasi penting antara kualitas pelayanan dan loyalitas konsumen didukung oleh penelitian ini. Karena dampak dari kualitas pelayanan yang dirasakan jauh lebih besar mengarah ke disposisi yang lebih menguntungkan terhadap penyedia layanan dan dapat meningkatkan komitmen untuk kembali berlangganan (Parvez \& Akbar, 2009).

Menurut Wyckof dan Lovelock (Sugiarto, 1999), kualitas jasa adalah tingkat keunggulan yang diharapkan dan pengendalian atas tingkat keunggulan tersebut untuk memenuhi keinginan pelanggan. Dengan kata lain, ada faktor utama yang mempengaruhi kualitas pelayanan, yaitu expected service dan perceived service (Sugiarto, 1999). Jika kualitas pelayanan yang diterima atau dirasakan (perceived service) sesuai dengan yang diharapkan (expected service), maka kualitas pelayanan tersebut akan dianggap baik dan memuaskan. Jika kualitas pelayanan yang diterima melampaui harapan, maka kualitas pelayanan dipandang ideal. Sebaliknya, jika kualitas pelayanan yang diterima lebih rendah daripada yang diharapkan, maka kualitas pelayanan itu dianggap buruk. Jadi baik dan buruknya kualitas pelayanan tergantung pada kemampuan karyawan dalam memenuhi harapan konsumen secara konsisten.

Kontak komunikasi antara karyawan dan konsumen pada proses pelayanan yang terjadi berpengaruh terhadap tingkat kepuasan konsumen. Namun dalam penelitian ini, kepuasan konsumen yang dipengaruhi oleh komunikasi interpersonal hanya memberikan pengaruh yang lebih sedikit daripada kualitas pelayanan. Nilai sumbangan efektif komunikasi interpersonal terhadap kepuasan konsumen yaitu sebesar $5,7 \%$. Penelitian terdahulu juga menunjukkan bahwa kontak interpersonal antara pramuniaga dengan konsumen menjadi faktor penting yang memengaruhi kepuasan dan loyalitas konsumen terhadap perusahaan ritel (Surya \& Setiyaningrum, 2009). Sedangkan penelitian yang dilakukan oleh Subarki dan Silalahi (2008) menunjukkan adanya hubungan yang positif antara kredibilitas dengan konteks komunikasi interpersonal dengan sikap nasabah terhadap perusahaan .

Dalam penelitian ini komunikasi interpersonal menunjukkan bahwa karyawan sudah memiliki ketrampilan berkomunikasi yang cukup baik, sehingga komunikasi interpersonal yang terjalin antara karyawan dengan konsumen dapat berhasil. Hal ini senada dengan penelitian yang dilakukan oleh Kirchmajer dan Patterson (2003) bahwa komunikasi interpersonal merupakan penentu utama kepercayaan antara layanan profesional (dalam hal ini kasus perencanaan keuangan) dan klien. Keterampilan mendengarkan, antusiasme yang ditunjukkan, diskusi terbuka dan jujur (berlabel komunikasi kejelasan) diperlukan untuk meyakinkan klien bahwa penasihat keuangan perlu memiliki ketrampilan professional dalam hal berkomunikasi dengan klien.

Menurut De Vito (1997), komunikasi interpersonal yang efektif ditandai oleh, 
keterbukaan, empati, sikap mendukung, sikap positif dan kesetaraan. Keterbukaan dapat diartikan sebagai sikap yang menunjukkan penerimaan terhadap orang lain atau orang yang diajak berinteraksi. Dalam hal ini komunikasi karyawan dengan konsumen sangat memerlukan keterbukaan, sikap keterbukaan sangat penting untuk menyampaikan suatu gagasan atau pendapat agar tidak terjadi kesalahpahaman dan penyimpangan. Selain itu sikap terbuka diperlukan untuk menggali informasi dari konsumen. Kecakapan kedua agar komunikasi interpersonal efektif maupun berhasil adalah rasa empati, yaitu merasakan sesuatu seperti orang yang mengalaminya, berada dalam keadaan yang sama, dan merasakan perasaan hal yang sama dengan cara yang sama (sudut pandang orang lain).

Dalam kondisi ini diharapkan seorang karyawan dapat memahami keadaan maupun kondisi konsumen, apa yang dirasakan oleh konsumennya. Karyawan yang memiliki empati terhadap konsumennya dalam berkomunikasi akan membuat konsumen dalam suasana yang nyaman dan harmonis. Kecakapan ketiga yang perlu diperhatikan agar komunikasi interpersonal karyawan dapat efektif, yaitu perlunya sikap mendukung pada saat berkomunikasi maupun berinteraksi dengan konsumen, maksudnya yaitu bersikap secara deskriptif jangan evaluatif atau menilai serta bersikap profesional atau berfikir terbuka serta bersedia mendengarkan pandangan yang berlawanan. Kecakapan keempat yang perlu diperhatikan dalam komunikasi interpersonal agar berhasil adalah bersikap positif terhadap orang yang kita ajak berinteraksi atau berkomunikasi. Dalam hal ini secara positif karyawan mendorong konsumen menjadi teman dalam berinteraksi. Komunikasi dengan cara tersebut sangat penting karena dengan memiliki rasa positif maka karyawan dapat memberikan informasi yang baik dan jelas kepada konsumennya dalam memberikan pelayanan.

Kesetaraan dalam berkomunikasi adalah kecakapan yang terakhir agar komunikasi interpersonal dapat efektif, yaitu adanya pengakuan secara diam-diam bahwa kedua pihak sama-sama bernilai dan berharga, dan bahwa masing-masing pihak mempunyai sesuatu yang penting untuk disumbangkan pada saat berinteraksi. Komunikasi yang dilakukan antara karyawan dengan konsumen dalam hal ini sangat penting, misalnya memberikan kesempatan pada konsumen untuk bertanya dan menghargai pendapat yang disampaikannya dengan menjawabnya secara baik dan ramah.

\section{SIMPULAN DAN SARAN}

\section{Simpulan}

Hasil penelitian ini membuktikan bahwa hipotesis yang berbunyi ada pengaruh positif komunikasi interpersonal dan kualitas pelayanan terhadap kepuasan konsumen dapat diterima. Semakin tinggi kemampuan komunikasi interpersonal dan kualitas pelayanan yang diberikan oleh karyawan, maka semakin tinggi kepuasan konsumen. Sebliknya, semakin rendah kemampuan komunikasi interpersonal dan kualitas pelayanan yang diberikan oleh karyawan, maka semakin rendah pula kepuasan konsumen. Selain itu, didapatkan hasil bahwa komunikasi interpersonal berpengaruh terhadap kepuasan konsumen dan kualitas pelayanan juga berpengaruh terhadap kepuasan konsumen. Namun kualitas pelayanan lebih besar dalam memberikan sumbangannya daripada komunikasi interpersonal sehingga kualitas pelayanan lebih berperan dalam upaya peningkatan kepuasan konsumen.

\section{Saran}

Berdasarkan hasil penelitian dan analisis serta simpulan data-data penelitian, maka peneliti mengajukan saran-saran sebagai berikut:

1. Bagi Perusahaan (Kalimilk)

Disarankan bagi perusahaan (Kalimilk) untuk melakukan evaluasi terhadap pelayanan yang telah diberikan selama ini dan diharapkan secara berkala sehingga konsistensi pelayanan yang diberikan dapat terjaga.

2. Bagi Karyawan. Diharapkan para karyawan dapat mempertahankan dan 
meningkatkan kualitas pelayanan dan menjalin hubungan yang baik dengan para konsumen. Untuk menjaga kualitas pelayanan yang ada hendaknya tujuan dari perusahaan tentang pelayanan harus ditekankan kepada karyawan, seperti visi dan misi perusahaan, agar karyawan dapat memahami secara mendalam akan tugasnya yang diharapkan dapat memberikan suatu pelayanan yang maksimal kepada konsumen, seperti keramahan dalam melayani konsumen.

3. Bagi Manajer

Diharapkan untuk terus meningkatkan mutu dan pelayanan yang selalu lebih baik kepada para konsumen. Karena hasil dari penelitian menunjukkan bahwa mayoritas tingkat kepuasan konsumen berada pada kategori tinggi namun ada juga yang masuk ke dalam kategori rendah. Hal ini menujukkan bahwa ketidakpuasan konsumen masih dirasa oleh beberapa konsumen dalam pelayanan yang diberikan karyawan di Kalimilk. Untuk itu tim manajemen sebagai tim pelaksana perusahaan sebaiknya memberikan pelatihan untuk meningkatkan kualitas pelayanan yaitu, seperti memberikan pelatihan mengenai service excellent kepada karyawan yang bertugas di bagian pelayanan.

4. Bagi Peneliti Selanjutnya

Dilihat dari hasil yang diperoleh terlihat bahwa komunikasi interpersonal dan kualitas pelayanan telah memberikan sumbangan efektif $60,3 \%$ terhadap kepuasan konsumen. Hal ini berarti masih terdapat sumbangan efektif lain yang dapat mempengaruhi kepuasan konsumen. Saran yang dapat diberikan adalah peniliti selanjutnya dapat menambah variabel lain yang mungkin dapat mempengaruhi kepuasan konsumen antara lain persepsi nilai, harapan dan kepercayaan, brand equity. Selain itu perlu dikontrol kelemahankelemahan yang terdapat dalam penelitian ini.

\section{DAFTAR PUSTAKA}

De Vito, J.A. (1997). Komunikasi Antar Manusia. (terjemahan: Agus Maulana). Jakarta: Professional Books

Gerson, R.F. (2004). Mengukur Kepuasan Pelanggan. Jakarta: Penerbit PPM

Kirchmajer, \& Patterson, P.P. (2003). The Role of Interpersonal Communication in the Development of Client Trust and Closeness in a SME Professional Service Context. $A$ paper for the Small EnterpriseAssociation of Australia and New Zealand, 16th, 2-12

Kotler, P., \& Armstrong, G. (1999). Marketing: An introduction, Third Edition.New Jersey: Prentice Hall

Weitz, B.A. \& Levy, M. (2000). Retailing Management. The McGraw-Hill Companies, Inc

Parvez, N., \& Akbar, M.M. (2009). Impact of Service Quality, Trust, and Customer Satisfaction on Customer Loyalty.ABAC Journal, 29(1), 24-38

Putra, I.W.J.A. (2009).Pengaruh Kualitas Pelayanan terhadap Kinerja Kerelasian Nasabah.Jurnal Ekonomi Bisnis, 14(2), 151-160

Subarki, N. \& Silalahi, S.M.E. (2008). Pengaruh Kredibilitas Pegawai dalam Komunikasi Interpersonal terhadap Sikap Nasabah pada Perusahaan. Jurnal Administrasi Bisnis, 4(1), 1-13.

Sugiarto, E. (1999).Psikologi Pelayanan dalam Industri Jasa. Jakarta: PT. Gramedia Pustaka Utama

Surya, A \& Setiyaningrum, A. 2009.Analisis Persepsi Konsumen pada Aplikasi Bauran Pemasaran Serta Hubungannya Terhadap Loyalitas 
Konsumen (Studi Kasus pada Hypermart Cabang Kelapa Gading).Journal of Business Strategy and Execution, 2, 13-39

Tjiptono, F. (1996). Manajemen Jasa. Yogyakarta: Andi Offset

Wijoyo \& Wahyuddin. (2005). Studi tentang Kualitas Pelayanan dan KepuasanKonsumen di Rumah Sakit Manisrenggo Klaten Surakarta. Buletin Psikologi, 4 (2), 65 - 74.

Zeithaml, V.A., \& Bitner, M. J. (2000). Service Marketing: Integrating Customer Focus Across the Firm. Second Edition. New York: The McGraw-Hill Companies 